\title{
LA AMBIVALENCIA COMO RASGO DEFINITORIO DEL DISCURSO DE OXFAM INTERMÓN SOBRE LAS MUJERES DEL SUR
}

\section{THE AMBIVALENCE AS A MAIN CHARACTERISTIC OF OXFAM INTERMÓN'S DISCOURSE ABOUT SOUTHERN WOMEN}

LAURA IBÁÑEZ

\author{
Author / Autora: \\ Laura Ibáñez \\ Universidad de Málaga \\ Málaga, Spain \\ laura.ibanez@uma.es \\ https://orcid.org/0000-0002-0877-3441
}

Submitted / Recibido: 13/02/2020

Accepted / Aceptado: 16/04/2021

To cite this article / Para citar este artículo: Ibáñez, L. (2022). La ambivalencia como rasgo definitorio del discurso de Oxfam Intermón sobre las mujeres del sur.

Feminismo/s, 39, 149-180. https://doi.

org/10.14198/fem.2022.39.06

Licence / Licencia:

This work is licensed under a Creative Commons Attribution 4.0 International.

\section{(c) (1)}

(C) Laura Ibáñez

\section{Resumen}

En 2018, casos de abuso y explotación sexual sacudieron a las ONG de Desarrollo (ONGD). Estos hechos demostraron que las organizaciones no son ajenas a las dinámicas opresivas hacia la población femenina que se registran en otros ámbitos de la sociedad. Las ONGD han implementado una serie de medidas con la finalidad de atajar estos casos. A estas reflexiones y prácticas, se realiza en esta investigación una aportación adicional desde el ámbito de la comunicación. Para ello, analizamos la representación efectuada sobre las mujeres del Sur con el propósito de conocer si aún presentan al colectivo de manera victimista y paternalista. Asimismo, se estudia posibles cambios en la representación que se hayan podido desencadenar posteriormente a los sucesos acaecidos en 2018. Concretamente, se han analizado los boletines para socios/as de Oxfam Intermón durante los periodos 2015-2016 y 2018-2019. El principal resultado de la investigación evidencia que la característica predominante de la imagen que la ONGD construye en torno a las mujeres del Sur es la ambivalencia. La representación aún conserva elementos de corte asistencialista porque ellas son tenidas 
en cuenta por la ONGD en cuanto a su condición de víctimas y, en consecuencia, de beneficiarias de las intervenciones. No obstante, estos roles son combinados con otros recursos que permiten mostrarlas como agentes clave en los ámbitos doméstico, productivo y público. Así, son retratadas como actoras relevantes para las economías familiares en actividades como la agricultura o la ganadería y como importantes agentes comunitarios. Sin embargo, estas últimas funciones no están exentas de contrariedad, pues, en definitiva, se las interpreta como una ampliación y traslación de sus roles reproductivos a los espacios productivo y comunitario.

Palabras clave: ONGD; comunicación; imagen de las mujeres; roles de género.

\section{Abstract}

In 2018, matters of sexual exploitation and abuse affected Development NGOs (NGDOs). These cases proved that there are the same oppressive dynamics towards women in these organizations than in all society sections. NGDOs have taken steps to stop these cases. Now, in this investigation, we want to add some thoughts about their communication. We analyse the southern women representation carried out by the NGDOs to find out if they maintain the victimized and paternalistic characterization about the collective. In addition, we study possible changes in the representation that may have been triggered after the events that occurred in 2018. Specifically, we analyse the bulletins for associates of Oxfam Intermón during two periods, 2015-2016 and 2018-2019. The main result of the research shows that the predominant characteristic of the image that the NGDO builds around the southern women is ambivalence. The representation conserves assistance attributes because they are taken into account by the NGDO in terms of their status as victims and, consequently, as beneficiaries of the interventions. However, these roles are combined with other resources which present southern women as a fundamental agent of their families, productive employees and societies. Thus, they are portrayed as relevant actors for family economies in activities such as agriculture or livestock and as important community agents. However, these latter functions are not exempt from contradictions, since, ultimately, they are interpreted as an expansion and transfer of their reproductive roles to productive and community spheres.

Keywords: NGDO; communication; women image; gender roles.

\section{INTRODUCCIÓN}

El 9 de febrero de 2018 The Times destapaba los casos de abusos sexuales cometidos por el personal de la filial británica de Oxfam durante la misión 
humanitaria desplegada por la ONG de Desarrollo (ONGD) tras el terremoto de Haití de 2010. La investigación realizada por la entidad se saldó con cuatro despidos y tres dimisiones, incluida la del director de la organización en Haití durante los sucesos, Roland van Hauwermeiren, aunque, como contribuyó al esclarecimiento de los mismos, no se le impuso ninguna medida disciplinaria (O'Neill, 2018). Posteriormente, The Guardian y The Observer desvelaron nuevos casos de conductas sexuales inapropiadas en las filas de Oxfam. En 2006, una misión de la ONGD, de nuevo capitaneada por van Hauwermeiren, pagó a mujeres a cambio de sexo en Chad (Ratcliffe y Quinn, 2018).

Comenzaba así el particular \#Metoo de la cooperación internacional. A medida que se realizaban nuevas averiguaciones, resultaba evidente que el comportamiento del personal de Oxfam constituía un problema generalizado en el sector. Según la encuesta publicada por la Fundación Thomson-Reuters en noviembre de 2018, con datos referentes a 21 organizaciones dedicadas a la cooperación y la ayuda humanitaria, a las que se les preguntó directamente sobre los casos de abusos y conductas sexuales inapropiadas, en 2017, Save the Children, Oxfam y Médicos Sin Fronteras habían despedido a 16, 22 y 20 personas respectivamente por este tipo de actos. El Consejo Noruego para los Refugiados había investigado 13 casos de abuso sexual que se tradujeron en cinco despidos. Por su parte, CARE International informó de 11 despidos y de 4 salidas de la organización porque las personas empleadas renunciaron, no se renovaron sus contratos o abandonaron la entidad ${ }^{1}$.

Meses después de la primera noticia, en julio de 2018, el Comité de Desarrollo Internacional del Parlamento británico concluía en su informe que los casos de abuso y acoso sexual representaban un fenómeno «endémico», que los hechos conocidos hasta el momento no eran sino «la punta

1. Se pueden consultar los datos relativos al resto de ONGD en Alonso (14 de febrero de 2018). Abusos sexuales: sólo seis de las diez grandes ONG internacionales acceden a revelar sus datos. Actualidad humanitaria. https://actualidadhumanitaria.com/abusos-sexuales-solo-seis-de-las-diez-grandes-ong-internacionales-acceden-a-revelar-sus-datos/ y Alonso (22 de febrero de 2018). Abusos en ONG: en 2017 fueron despedidos al menos 124 trabajadores por mala conducta sexual. Actualidad humanitaria. https:// actualidadhumanitaria.com/abusos-en-ong-en-2017-fueron-despedidos-mas-de-120trabajadores-por-mala-conducta-sexual / 
del iceberg» y que la respuesta de las ONGD había estado más centrada en su reputación que en el daño causado a las víctimas (Efe, 2018).

En este sentido, según relata Shaista Aziz (2018) en un artículo publicado por eldiario.es, en sus más de 15 años como trabajadora humanitaria se topó con «una cultura de acoso, en la que las mujeres a menudo eran menospreciadas y el racismo era habitual» en muchas de las organizaciones a las que perteneció. Tal como indica, existe «una suerte de 'puerta giratoria' entre muchas de las agencias, de forma que los hombres que han sido marcados como 'no amables' por las mujeres van pasando de una agencia a otra ${ }^{2}$. Siempre según la misma autora, impera una «cultura masculina» en las ONGD británicas más grandes, dirigidas mayoritariamente por hombres blancos, pero también por algunas mujeres blancas. Los casos hechos públicos contribuían, pues, a visibilizar que, en estas entidades, se reproducen las mismas jerarquías que en el resto de la sociedad, siendo los hombres blancos de clase media-alta quienes ostentan las más altas cuotas de poder (Tyner y Ogle, 2009, p. 100).

Como respuesta ante estos sucesos, las ONGD han emprendido medidas para mejorar los cauces de denuncia, la transparencia, la sensibilización de su personal, etc. ${ }^{3}$ con el objetivo de reforzarse frente a posibles casos futuros, pero también con la intención de recuperar la maltrecha confianza que la sociedad depositaba en ellas. Creemos necesaria y oportuna una reflexión adicional sobre la comunicación realizada por estas organizaciones. Si, como argumenta Erro (2002, p. 25), «cuando las ONGD eligen su estilo de comunicación no sólo difunden mensajes: están construyendo el marco de solidaridad y cooperación en el que se insertan y se están educando y transformando ellas mismas $»^{4}$, consideramos que las entidades también se han de replantear su comunicación y, en concreto, la imagen que promueven sobre

2. Comillas de la autora.

3. Como ejemplos, se pueden consultar las medidas emprendidas por Oxfam Intermón en https://www.oxfamintermon.org/es/contra-acoso-explotacion-sexual y por Médicos Sin Fronteras en https://www.msf.es/ combatimos-abuso-la-explotacion-y-acoso-nuestro-entorno-laboral.

4. Cursiva del autor.

Feminismo/s 39, January 2022, 149-180 
las mujeres del Sur ${ }^{5}$, para asegurarse de que esta no reproduce estereotipos que, en último término, contribuyen a reforzar una posición subalternizada del colectivo, que, a su vez, hace más permisibles las prácticas de abuso y explotación sexual que se ha comprobado existen en el sector.

\section{LAS MUJERES DEL SUR EN LA COMUNICACIÓN DE LAS ONGD}

Cada mensaje difundido por una ONGD contiene tres elementos básicos (Nos Aldás, 2007, 2010, 2019). Primeramente, refleja su propuesta de desarrollo y cooperación. Esta puede basarse en criterios de corte caritativo y asistencialista o tender hacia la consolidación de procesos colaborativos justos e igualitarios entre Norte y Sur. Asimismo, visibiliza los lazos que entreteje con las comunidades del Sur. Por tanto, puede promocionar relaciones jerárquicas, dependientes e, incluso, neocoloniales o, por el contrario, estimular vínculos horizontales, igualitarios y cooperativos. Finalmente, transmite la concepción que la entidad maneja sobre su público que puede ser imaginado como receptor pasivo de mensajes y donante o como sociedad civil y opinión pública. Se distinguen así dos grandes corrientes en la comunicación del sector, la primera de marcado carácter asistencial y caritativo y la segunda de cariz transformador.

Atendiendo, pues, al segundo elemento vehiculizado por los mensajes de las ONGD, las organizaciones se han vinculado a la cara más dramática del Sur (hambruna, enfermedad, violaciones de derechos, conflictos armados, etc.) (Garrido, 2007; Herranz de la Casa, 2007; Martínez Sánchez, 1998; Rizzardini, 2002). Hasta cierto punto, esta imagen quedaba justificada por el hecho de que las entidades fueron ideadas para contrarrestar

5. Llegadas a este punto, es preciso aclarar a qué nos referimos con los conceptos de Norte y Sur. En ningún caso se los ha de entender en sentido geográfico, pues, siguiendo a Marcellesi (2012, p. 14), no todos los países industrializados están emplazados en la zona norte del globo. Además, en la medida en que las élites del Sur ostentan patrones de producción, consumo y bienestar similares a los del Norte, se las considera parte de él. Así pues, como razona Santos (2011, p. 16), el Sur deviene en una «metáfora del sufrimiento sistemático producido por el capitalismo y el colonialismo, así como por otras formas que se han apoyado en ellos como, por ejemplo, el patriarcado. Es también el Sur que existe en el Norte, lo que antes llamábamos el tercer mundo interior o cuarto mundo: los grupos oprimidos, marginados, de Europa y Norteamérica».

Feminismo/s 39, January 2022, 149-180 
estas problemáticas, por lo que se entendía que sus mensajes contribuían a visibilizarlas. Asimismo, la urgencia por recolectar recursos para lograr una rápida actuación frente a las crisis las impelía a emplear estrategias comunicativas con las que provocar, principalmente, una respuesta emocional e impactante en el público occidental para moverlo a la realización de donativos. Sin embargo, esta comunicación se fue consolidando en el sector tanto para informar sobre dichas crisis como para captar recursos con los que poner en marcha intervenciones de más largo recorrido encaminadas a iniciar procesos de desarrollo duradero (Nos Aldás, 2007, 2010, 2019). De este modo, las ONGD usaron y abusaron de imágenes y mensajes cada vez más extremos y patéticos sobre el Sur sin tener en cuenta o incluso contradiciendo sus objetivos de educación y transformación social (González Luis, 2006; Picas Contreras, 2001). En definitiva, privilegiaron la primera modalidad de comunicación frente a la segunda.

En consecuencia, la imagen que se ha trasladado a la ciudadanía del Norte, tanto desde las ONGD, pero también desde las fotografías con intención documental y de denuncia, como advierte López García (2005), es la de un Sur plagado de víctimas indefensas, pasivas y necesitadas urgentemente de la ayuda occidental (González Luis, 2006; Iranzo et al., 2015; Iranzo, 2017; Nerín, 2011; Nos Aldás, 2003; Santolino, 2010). Además, las comunidades del Sur han sido desplazadas del foco de atención, pues este se ha centrado en la actuación de las ONGD. Las entidades se han mostrado especialmente preocupadas por cuantificar el volumen de la ayuda (Iranzo et al., 2015; Iranzo, 2017), implicando con ello que más cantidad de asistencia humanitaria es sinónimo de más y mejor ayuda.

Sin embargo, no todos los colectivos han sido empleados en igual medida para poner rostro a este Sur marcado por la tragedia. Las ONGD han contribuido a generar una serie de imágenes icónicas entre las que sobresalen las mujeres indígenas y las y los menores africanos (Santolino, 2010, p. 243). Centrándonos en las primeras, foco de atención del presente estudio, diferentes autoras y autores han subrayado la masiva presencia de mujeres del Sur en los mensajes de las ONGD (Bringas, 2010; Flores Martos, 2018; Martín Nieto, 2009; Saiz, 2007). Estas no sobresalen únicamente por su número, sino también por el tipo de caracterización bajo la que se las ha presentado, sobre todo en los mensajes publicitarios: 
La ambivalencia como rasgo definitorio del discurso de Oxfam Intermón sobre

las mujeres del sur

[P]revalece la representación descontextualizada de mujeres africanas de piel muy oscura, que responden al estereotipo de madre pobre. El cuerpo femenino, con frecuencia no mostrado en su totalidad sino fragmentado [...], es aquí también el significante de la diferencia y se trata asimismo de un cuerpo fetichizado y estetizado, reducido en este caso a su función reproductiva, con la intención de mostrarnos la distancia abismal entre 'nosotros/as' y 'ellos/as', por más que en el eslogan se apele a nuestros puntos en común (Bringas, 2010, p. 132).

Mostrar a las mujeres del Sur como madres, amas de casa y encargadas de la cobertura de las necesidades familiares, sobre todo en contextos marcados por graves carencias y en los que la vida está en riesgo, se ha convertido en una caracterización recurrente y estereotipada entre las ONGD (Porras y Molina, 2011, p. 35). Esta clase de representación refuerza la creencia de que las mujeres se encuentran al servicio de otros, en este caso de sus familias y, sobre todo de las y los menores. Asimismo, al considerar a las mujeres y a la población infantil como un grupo único, se traslada, por asociación, la indefensión de la segunda a las primeras, puesto que se deduce que el primer colectivo, en plena posesión de sus capacidades, es igual a otro vulnerable debido a que todavía no ha concluido su proceso madurativo. Siguiendo a Castro Vázquez (2010, p. 103): «La equiparación de mujer e infancia (frecuente en contextos de emergencias) constituye una actitud paternalista que muestra al hombre como protector con el ser débil, vulnerable y dependiente». Se configura así, simbólicamente, un Sur infantil y femenino, frente a un Norte, adulto y masculino, encargado de salvaguardarlo.

Además de esta caracterización como madres y cuidadoras, las mujeres han sido retratadas como víctimas y beneficiarias, quedando al margen de otro tipo de roles como, por ejemplo, cooperantes, voluntarias, etc. (Saiz, 2007, p. 241). La población femenina, tanto adulta como infantil en este caso, ha sido empleada para poner rostro a la pobreza extrema en campañas de recaudación de fondos (Betrisey y Gordo, 2007, p. 99), reforzando, en consecuencia, el estereotipo de que «las mujeres necesitan ayuda y en muy pocas ocasiones son capaces de canalizarla» (Martín Nieto, 2009, p.169). Se trata, de nuevo, de una representación cargada de paternalismo.

Asimismo, la representación ha derivado en otro efecto colateral. Prácticas culturales que atañen a las mujeres como la ablación del clítoris o el uso de determinadas prendas como el burka o la hiyab que, desde 
el punto de vista occidental, resultan mayoritariamente reprobadas, han sido utilizadas para estigmatizar y descalificar a otras sociedades. Como argumenta Gregorio (2009, p. 52), la denuncia instrumentalizada de tales prácticas sirve, a un mismo tiempo, para construir una imagen positiva sobre el Norte, que se reimagina a sí mismo como «salvador» de las mujeres «oprimidas», y para invisibilizar las prácticas opresivas que sufre su propia población femenina. Como la misma autora refiere, este tipo de imágenes engañosas oculta los esfuerzos que las mujeres emprenden en sus propias comunidades para liberarse de la dominación, ya que las conciben como seres desposeídos de agencia.

Si bien es cierto que los mensajes de las ONGD sobre el Sur pueden no resultar enteramente satisfactorios, es preciso reconocer los esfuerzos que han emprendido para comenzar a adoptar una comunicación más transformadora. En los últimos años, han producido una serie de investigaciones que tienen como objetivo tanto proponer una mirada crítica sobre sus narrativas y la ideología que las sustenta como plantear un relato alternativo sobre las realidades del Sur. En tal sentido, son destacables la publicación de Darnton y Kirk (2011) Buscando marcos: nuevas formas de implicar a la ciudadanía del Reino Unido con la pobreza global, promovida por Oxfam UK, como, en España, el estudio Nadie dijo que fuera fácil. Un relato colectivo, optimista y cuestionador sobre cómo las ONG implicamos a la ciudadanía (Gómez Pérez et al., 2019), realizado por ONGAWA.

Los estudios suponen una aportación añadida a las recomendaciones realizadas al conjunto del sector desde la Coordinadora de ONG para el Desarrollo-España (en adelante, la Coordinadora). Esta red de organizaciones y plataformas sociales ha elaborado un Código de conducta de las ONG de Desarrollo (Coordinadora de ONG para el Desarrollo-España, 2019a), de carácter general, y un documento complementario en el que se desarrollan las pautas comunicativas, denominado Guía práctica para la comunicación de las ONGD (Coordinadora de ONG para el Desarrollo-España, 2019b). En ambos, se insta a tratar a la ciudadanía del Sur de manera digna, así como a presentarla en sus contextos económico, social, cultural, etc. Igualmente, se subraya el hecho de que, preferentemente, ha de ser la protagonista de los mensajes y su voz se ha de privilegiar sobre la de terceros. En cuanto a las pautas directamente relacionadas con la presente investigación, el código de

Feminismo/s 39, January 2022, 149-180 
conducta de carácter genérico (Coordinadora de ONG para el DesarrolloEspaña, 2019a, p. 15) propone: «Los mensajes denunciarán las desigualdades de género como fruto de un sistema patriarcal que viola los Derechos Humanos y sitúa a mujeres y hombres en posiciones inequitativas».

Por su parte, la guía práctica incorpora un apartado, intitulado «enfoque de género», en el que se desarrolla a través de nueve recomendaciones el tratamiento que se ha de dispensar a las mujeres del Sur, así como a personas con identidades no binarias (Coordinadora de ONG para el DesarrolloEspaña, 2019b, pp. 29-32). Centrándonos en las primeras, se propone reconocer y ceder espacio a «las voces, experiencias y puntos de vista de las mujeres como sujetos activos del desarrollo, profesionales, expertas, líderes, supervivientes, etc.» (Coordinadora de ONG para el Desarrollo-España 2019b, p. 31). De acuerdo con ello, se aboga por mostrarlas en una amplia diversidad de papeles para transcender la clásica división de roles asignada en función del género al tiempo que se impele a no reproducir «estereotipos y roles que perpetúen las desigualdades de género» (Coordinadora de ONG para el Desarrollo-España, 2019b, p. 31). No obstante, se considera que las ONGD también han de construir discursos que valoricen la importancia de los cuidados y otras tareas indispensables para la vida. Se recomienda tener un especial cuidado con las mujeres racializadas y subalternizadas, huyendo de una caracterización prejuiciosa y/o estereotipada y visibilizándolas como expertas en los diferentes temas tratados por las ONGD. Si bien se apuesta por mostrar a mujeres empoderadas, se insta a no «caer en ejemplos reduccionistas» (Coordinadora de ONG para el Desarrollo-España, 2019b, p. 32). Con respecto a las propuestas concretas correspondientes a la representación visual, se exhorta a eliminar planos que connoten relaciones de poder desequilibradas como aquellos en los que aparecen hombres delante y mujeres en segundo plano, así como evitar cosificar los cuerpos femeninos.

Teniendo en cuenta lo anteriormente apuntado, la investigación que planteamos tiene como objetivo general describir la representación que Oxfam Intermón efectúa sobre las mujeres del Sur. Se quiere descubrir si sus mensajes continúan reforzando estereotipos asociados a una comunicación de cariz caritativo y asistencialista o si, por el contrario, proponen otro de tipo de representación(es) más acordes con una comunicación transformadora. Asimismo, se desea conocer si se han producido cambios en el trato 
dispensado a la ciudadanía femenina del Sur en la representación tras el desvelamiento de los recientes casos de abusos y explotación sexual detectados en el sector.

\section{METODOLOGÍA}

Para llevar a cabo el estudio, se decidió analizar la comunicación de Oxfam Intermón. El interés por esta ONGD viene motivado por el hecho de que es una organización referente en el ámbito de la cooperación internacional. Siguiendo a Santolino (2010, p. 229), han sido las ONGD más grandes las que se han convertido en la imagen pública del sector y las que han fijado en el imaginario colectivo el discurso sobre el Sur y sobre la cooperación internacional. Así pues, en términos cuantitativos, es la entidad con más fondos privados procedentes de cuotas periódicas y la tercera por donaciones puntuales, de acuerdo con el último Informe del sector de la Coordinadora de ONG para el Desarrollo-España (2019c), elaborado con datos de 2017 y 2018. Se trata, además, de la segunda ONGD más importante por ingresos públicos y por número de socias y socios y la cuarta por personal voluntario.

Desde un punto de vista más cualitativo, Oxfam Intermón cuenta con una línea de intervención específica destinada a la población femenina denominada «Derechos de las mujeres», una muestra de su especial preocupación por el colectivo. A nivel comunicativo, la entidad promovió un taller online de comunicación y género ${ }^{6}$. En consecuencia, se deduce que no solo trabaja con mujeres sobre el terreno en los países del Sur, sino que tiene una visión holística que le lleva a preocuparse incluso por cómo es el tratamiento informativo que los medios de comunicación ofrecen sobre la población femenina y sobre las cuestiones de género. Por último, el desvelamiento de los casos de abusos y explotación sexual en el ámbito de la cooperación comenzó con la filial británica de Oxfam.

Concretamente, se han estudiado los boletines para socias y socios publicados durante el periodo comprendido entre 2015-2016 y 2018-2019. En todos los años, los números salieron a la luz en los meses de mayo, septiembre y diciembre. Se optó por este tipo de revistas porque, aunque su difusión

6. Se puede consultar en: https://www.informarsobreviolenciamachista.com/.

Feminismo/s 39, January 2022, 149-180 
no es mayoritaria, se entiende que el personal de la ONGD las confecciona sin condicionantes externos. Los periodos escogidos permiten comparar el tratamiento dado a la representación de la población femenina con anterioridad y posterioridad a los casos de abusos sexuales para comprobar así si los sucesos han podido cristalizar en un replanteamiento en los mensajes de la ONGD. De cada boletín, se extrajo la pieza periodística ${ }^{7}$ de mayor extensión. En total, se han estudiado 12 textos, seis para cada periodo.

La investigación presta atención a una serie de puntos básicos derivados de las recomendaciones formuladas por la Coordinadora y que se consideran adecuados para perfilar la representación de la población femenina adulta. Estos son los siguientes: 1) Número de mujeres y de hombres individuales que son mencionados en los textos; 2) Roles atribuidos a las mujeres del Sur; 3) Las mujeres como fuentes de información; y 4) Representación visual ofrecida sobre la población femenina adulta del Sur.

En primer lugar, resulta fundamental determinar si las mujeres están presentes en las piezas periodísticas o no, esto es, si se las tiene en cuenta y se las visibiliza. Por eso, se ha optado por contabilizar el número de mujeres que son mencionadas en los textos. Esta cifra se contrasta con la del número de hombres para saber si, en último término, el Sur es conceptualizado como un territorio femenino. Seguidamente, se profundiza en los roles que se les atribuyen para comprobar si se mantiene la imagen estereotípica que las concibe como víctimas, beneficiarias y madres fundamentalmente.

A través del primero, las mujeres son caracterizadas como colectivo objeto de múltiples adversidades. Este rol se pone en contraste con la figura de la superviviente, con la que se busca resaltar la capacidad de superación de quienes, en un determinado momento, han podido ser víctimas. Mediante el análisis de los roles que las mujeres desempeñan dentro de las intervenciones, se busca comprobar si son únicamente receptoras de las mismas o si, por el contrario, también contribuyen en alguna medida a su funcionamiento o directamente están implicadas en impulsarlas como miembros de las contrapartes locales.

7. Se emplea esta denominación porque, como indica Giró (2017, p. 89), permite aludir a cualquier tipo de género periodístico con la ventaja de soslayar la clásica división entre información y opinión.

Feminismo/s 39, January 2022, 149-180 
Por último, se sigue la distinción propuesta por Murguialday et al. (2008, p. 32) entre roles reproductivos, productivos y comunitarios para determinar el papel que se asigna en los textos analizados a la población femenina del Sur dentro de sus comunidades. De acuerdo con las autoras, el primero se refiere a las actividades relacionadas con la crianza de las y los menores, la atención a otros colectivos dependientes y las tareas relacionadas con el mantenimiento del hogar y la satisfacción de las necesidades familiares cotidianas. El rol productivo contempla actividades a través de las que se suele percibir un pago, ya sea en dinero, especie o servicios. Bajo esta categoría, se integran tanto tareas para obtener productos destinados al consumo de la familia, que les permiten ahorrar recursos (agricultura de subsistencia, por ejemplo), como a los mercados. Por último, el rol de gestión comunitaria incluye actividades de las que se beneficia la comunidad en general y que contribuyen a fortalecer los lazos entre sus miembros y generar redes de apoyo mutuo. Entre ellas, se incluye, asimismo, el trato con autoridades y la representación política de la comunidad que pueden derivar en la consolidación de liderazgos políticos.

Concluyendo el análisis en su vertiente textual, se valora el uso de las mujeres como fuentes de información para conocer ya no sólo si se las visibiliza en los textos, sino también si se les da voz para relatar los hechos que les atañen y la realidad de sus propios países. Se han clasificado las declaraciones en las mismas categorías recogidas en el Proyecto de Monitoreo Global de Medios (2015, p. 40), es decir, como experiencia personal, opinión popular, testigo, experta y portavoz. Las tres primeras atañen a gente que podría considerarse «ordinaria», ya que las personas citadas relatan los hechos desde la propia experiencia, manifiestan sus pareceres en calidad de ciudadanía general o aportan información por haber presenciado unos determinados sucesos respectivamente. Por el contrario, las fuentes expertas comparten comentarios que se basan en un conocimiento o práctica especializados mientras que quienes se erigen como portavoces representan y hablan en nombre de otra persona, un grupo o una organización. En la práctica, se comprobó que la distinción entre citas de experiencia personal y testigos no era del todo pertinente para las piezas analizadas, razón por la que se decidió crear una categoría única con ellas. 
Como las piezas periodísticas seleccionadas están compuestas por elementos de corte textual y visual, se las considera como textos multimodales. De acuerdo con Martínez Lirola (2010, p. 82), se entiende como tal un texto «en el que encontramos diferentes elementos, aquel que utiliza diferentes modos para la comunicación: el lingüístico (la lengua) y el visual (fotografías, diagramas, etc.)». Los diversos recursos con los que se construye este tipo de textos configuran, juntos, una unidad de significado y, por tanto, ninguno puede quedar fuera del análisis (Martínez Lirola, 2017). La relevancia de las fotografías deriva, además, en que son interpretadas generalizadamente como la captación de una parcela de la realidad. En palabras de Canga Larequi (1994, p. 118): «[P]uede afirmarse que si el 'texto' se encarga de narrar lo sucedido y el 'gráfico' de ofrecer una representación ideal del hecho, la 'fotografía' es la encargada de mostrar la imagen real de lo acontecido» ${ }^{8}$.

Así pues, en el análisis fotográfico, se ha prestado atención al sexo de las personas retratadas, de nuevo, con el objetivo de conocer si las mujeres resultan visibilizadas también en la parte visual de las piezas periodísticas. Además, se categoriza cada fotografía en función de los roles asignados al colectivo femenino teniendo en cuenta los ya explicados.

Se ha tratado de dar cuenta de la función interpersonal referida por Kress y Van Leeuwen (2006) ${ }^{9}$, que remite a las relaciones que, a nivel simbólico, se establecen entre quien es mostrado/a en una fotografía y quien la observa. Para ello, se han analizado los ángulos de cámara bajo los que se retrata a las mujeres del Sur, ya que estos pueden marcar simbólicamente diferentes relaciones de poder entre quien observa y quien es observada. Los ángulos a la altura de los ojos connotan relaciones equitativas. Por el contrario, un picado refleja un estatus desigualitario en detrimento de quien es retratada. En cambio, un contrapicado ubica a la observadora o al observador en plano de inferioridad con respecto a quien ha sido captada en la fotografía (de Silva y Gaudin, 2007; Kress y Van Leeuwen, 2006; Macken-Horarik, 2004).

8. Cursiva y comillas del autor.

9. Los autores adaptan las metafunciones del lenguaje de Halliday (1982) al análisis de las imágenes. Además de la función interpersonal, se encuentran la función ideacional, referida a las experiencias de quien habla o escribe así como a su visión del mundo; y la función textual, relativa a la coherencia entre los diversos elementos de un texto y su adecuación a una determinada situación comunicativa.

Feminismo/s 39, January 2022, 149-180 
Se evalúa, asimismo, la interacción con la cámara. En este sentido, se pueden distinguir dos tipos de imágenes: aquellas en las que las personas retratadas establecen contacto visual, a nivel simbólico, con quien las observa ('demand pictures') y aquellas en las que los sujetos retratados se muestran para ser escrutados, sin dirigir su mirada hacia el público ('offer pictures') (Kress y Van Leeuwen, 2006; Macken-Horarik, 2004). Las de primer tipo parecen interpelar directamente a quien las recibe solicitándoles una respuesta mientras que las de segundo tipo no formulan esta exigencia. Cada una de ellas conlleva un riesgo: las ONGD han utilizado las de primer tipo, sobre todo, para movilizar la compasión del público occidental y llevarlo a la realización de un donativo sin plantear una reflexión más profunda sobre los problemas globales mientras que las de segundo tipo pueden cosificar a la(s) persona(s) retratada(s).

\section{RESULTADOS}

\subsection{Representación textual de las mujeres del Sur}

Como primer resultado, sobresale la abundante presencia de mujeres del Sur en los textos de Oxfam Intermón. De manera global, aparecen 50 figuras femeninas adultas por tan solo 22 masculinas, es decir, la presencia de las primeras duplica a la de los segundos. Al menos una figura femenina individual es identificada en todos los textos excepto en uno (pieza 6), en el que no se alude específicamente a ninguna persona. No obstante, incluso en este último caso, se incluye una mención genérica a ellas como colectivo, junto a las y los menores, mientras que los hombres del Sur no son referenciados en ningún momento. Desgranando la presencia femenina por textos, ellas aparecen en exclusiva en un tercio de los casos analizados (piezas 4, 5, 10 y 11) y su presencia es mayoritaria en dos piezas más (piezas 1 y 8). Por su parte, los rostros masculinos son evocados mayoritariamente también en cuatro ocasiones (piezas 2, 7, 9 y 12), pero ellos nunca aparecen en solitario en ningún texto. Por último, se produce un estado de equilibrio entre figuras femeninas y masculinas en una pieza (3) (datos en la Figura 1).

Diferenciando entre los periodos analizados, se mantiene casi constante el número de mujeres y hombres individuales: en ambas muestras, son mencionadas 25 féminas mientras que, entre los varones, el primer periodo 
recoge 10 figuras masculinas por 12 registradas en el segundo. De hecho, en los dos conjuntos analizados, se encuentran sendos textos en los que solo aparecen mujeres (piezas 4 y 5 para las comprendidas entre 2015 y 2016 y piezas 10 y 11 para las publicadas entre 2018 y 2019) y una más en la que su presencia es mayoritaria (piezas 1 y 8 respectivamente). Probablemente, el punto más significativo se refiere al hecho de que los hombres consiguen ubicarse como actores individuales mayoritarios en un número mayor de piezas de la segunda muestra (piezas 7, 9 y 12). Dicho de otro modo, la presencia de mujeres en este compendio de textos está más concentrada en tres piezas $(8,10$ y 11) mientras que, en las otras tres, la de los varones es más sobresaliente.

Figura 1. Número de mujeres y hombres del Sur por piezas periodísticas

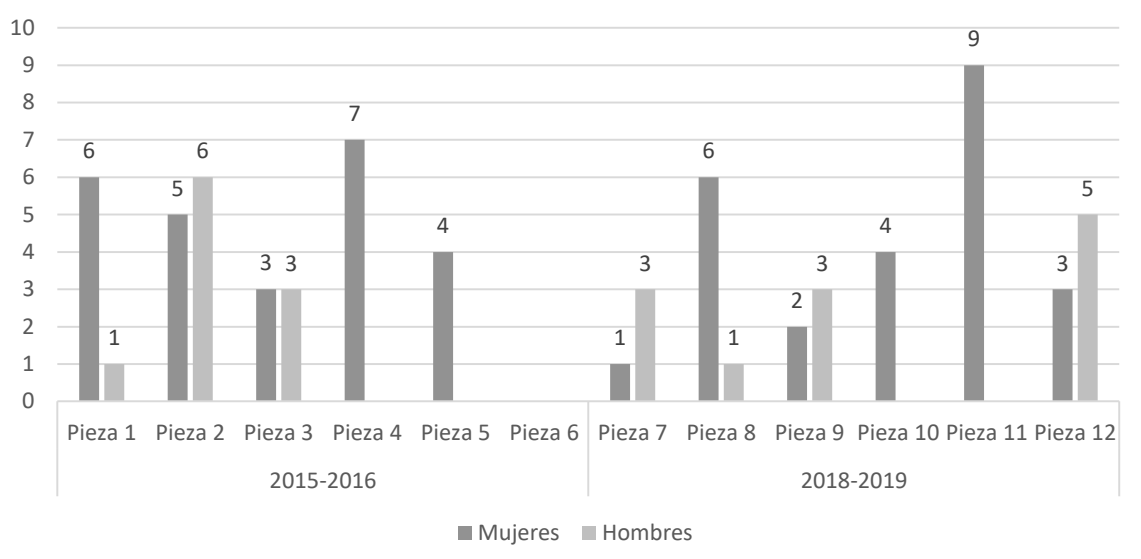

Fuente: elaboración propia

Con respecto a los roles, las mujeres han sido caracterizadas, principalmente, como beneficiarias, papel que se les atribuye en todos los textos analizados. Seguidamente, se ubica el de víctimas. Ambos roles van de la mano en la medida en que este último permite justificar la elección de las mujeres como colectivo receptor de las intervenciones. Sin embargo, su estatus como víctimas resulta un tanto más destacado en la segunda muestra que en la primera, pues se ha hallado en todas las piezas. Residualmente, se ha registrado en 
una ocasión la caracterización de las mujeres del Sur como supervivientes, un papel que desempeñan tan solo en una pieza de la primera muestra (datos en la Figura 2).

Pasando a evaluar los roles relacionados con el ámbito de la reproducción y los cuidados, las mujeres son, sobre todo, caracterizadas como madres tanto en la primera muestra como en la segunda. No obstante, en este último conjunto de textos, adquieren presencia mayoritaria otros dos roles propios del ámbito privado, el de esposas y el de encargadas de las tareas del hogar (recolección de agua y leña, lavado de la ropa, etc.) y de los cuidados, dirigidos prioritariamente a la infancia. Como abuelas, son retratadas en dos textos, repartidos entre las muestras. Por último, las piezas publicadas en el periodo comprendido entre 2015 y 2016 evocan un último rol relacional, el de hermanas, referenciado en una ocasión.

Entre los roles productivos, las mujeres son retratadas, fundamentalmente, como agricultoras, ganaderas y vendedoras/comerciantes (vendedoras de productos lácteos y agrícolas, propietarias de una tienda de ropa y de un restaurante, etc.). La principal diferencia entre las dos muestras con respecto a este punto es que la primera enfatiza en mayor medida la faceta de la población femenina como comerciante y vendedora mientras que la segunda la vincula preferentemente a las actividades del sector primario. El resto de roles productivos, con una presencia muy escasa, son, para la primera muestra, los de trabajadoras en la agroindustria (el sector de la fresa marroquí) y analistas políticas mientras que, para la segunda, los de empleadas en la industria láctea, una suerte de extensión de su función como ganaderas, tradicionalmente asumida por la población femenina en el país referido en la pieza, Burkina Faso, y profesoras. Asimismo, de manera residual, las mujeres aparecen como estudiantes universitarias, en el caso de la primera muestra, y migrantes, para la segunda.

Las funciones comunitarias que ellas asumen como consecuencia de su participación en las actividades de Oxfam Intermón son las más subrayadas con respecto al ámbito público. En concreto, sobresalen para las dos muestras lo que se ha denominado como «roles comunitarios», esto es, su desempeño como promotoras de salud y miembros de los comités de agua creados en torno a las intervenciones y como impulsoras de actividades de sensibilización sobre los derechos de las trabajadoras en el sector de la fresa, 
sobre prevención de riesgos frente a posibles inundaciones y sobre buenos hábitos de alimentación e higiene tras ser formadas por la ONGD. En la primera muestra, además, se subraya en mayor medida la pertenencia de las mujeres a organizaciones locales relacionadas con sus actividades productivas (la agricultura y la ganadería). Adicionalmente, se las retrata como integrantes de las cooperativas de comercio justo, rol que sorpresivamente, solo es evocado en una ocasión, a pesar de que Oxfam Intermón dedica una de sus líneas de intervención a esta modalidad de compra y consumo alternativa. Por su parte, en la segunda muestra, opta por representar a una mujer como miembro de la contraparte local con la que la ONGD desarrolla las intervenciones sobre el terreno. De nuevo, se trata de una función apenas visibilizada.

Figura 2. Roles asignados a las mujeres del Sur

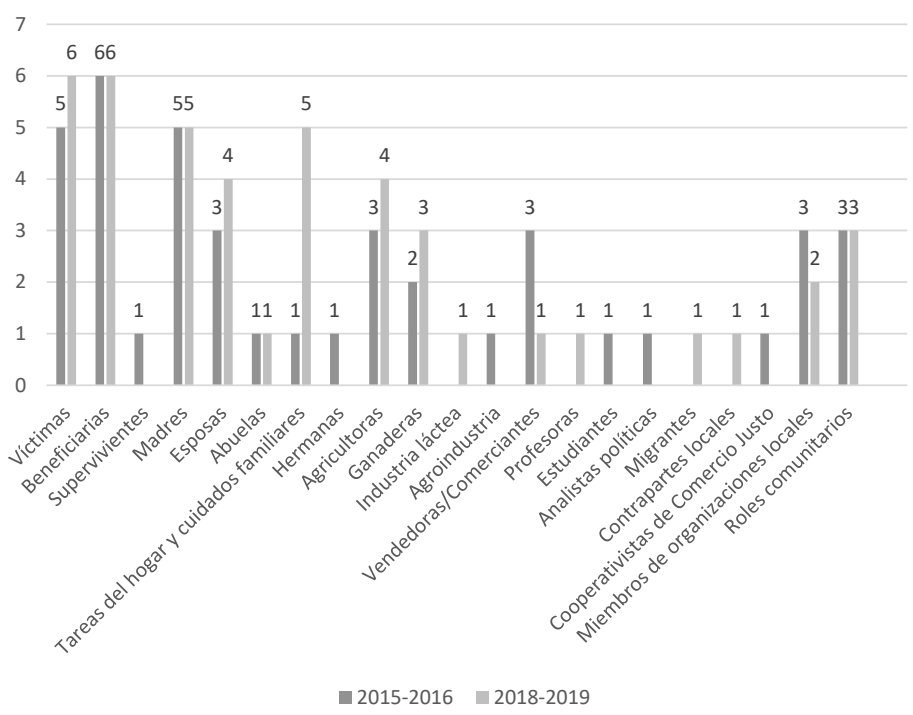

Fuente: elaboración propia

Pasando ahora a las fuentes de información, se ha contabilizado en el conjunto global de piezas un total de 29 voces femeninas por tan solo 10 masculinas. Este dato es congruente con el mayor número de figuras de mujer 
individuales encontrado. De este modo, dos piezas de la primera muestra y tres de la segunda recogen únicamente declaraciones procedentes de la población femenina del Sur (piezas 4 y 5 y 7, 10 y 11 respectivamente). Aunque el número de citas atribuidas a mujeres y hombres ha aumentado ligeramente en la segunda muestra (se pasa de 14 a 15 en el caso de las primeras y de 3 a 7 en el caso de los segundos), en el conjunto de textos publicado durante el periodo de 2015 y 2016, se ha detectado una convivencia de voces femeninas y masculinas en un mayor número de ocasiones (piezas 1, 2 y 3), encontrándose en un estado de equilibrio en dos de los textos. En cambio, se ha registrado una mayor polarización en la segunda muestra, con piezas en las que solo se han hallado declaraciones de fuentes femeninas (piezas 7, 10 y 11) o masculinas (piezas 8 y 9), existiendo únicamente un caso en el que se combinan citas adjudicadas a ambos sexos (pieza 12) (datos en el Figura 3).

Figura 3. Mujeres y hombres como fuentes de información

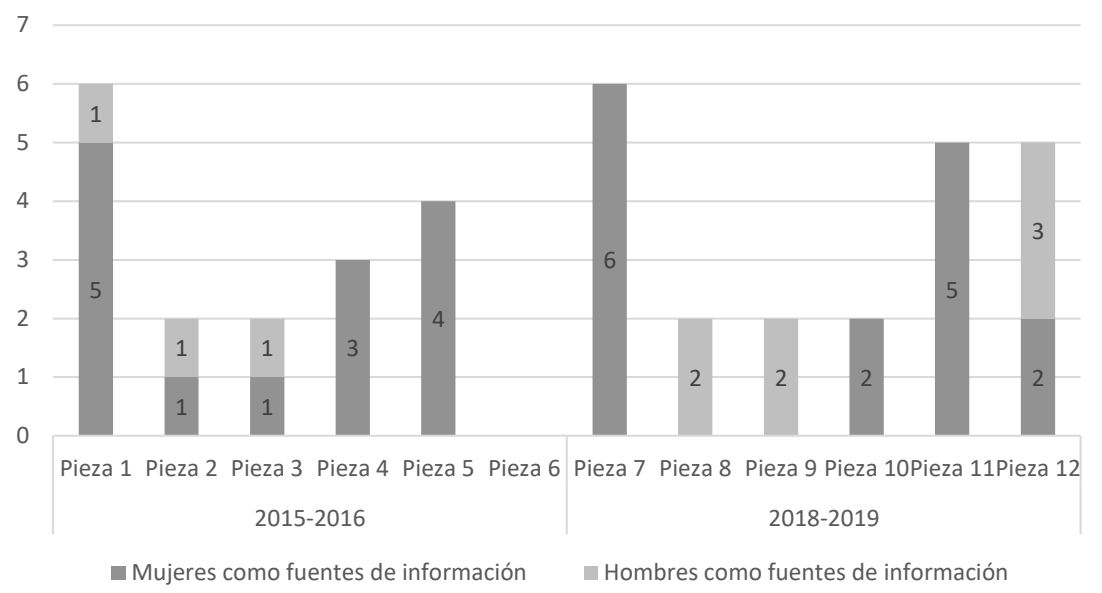

Fuente: elaboración propia

Con respecto al tipo de citas atribuidas a mujeres y hombres, predominan para ambos las declaraciones referidas a vivencias personales en las dos muestras. La variación más significativa que se registra a este respecto es el incremento de este tipo de citas adjudicadas a la población masculina en la 
segunda muestra (de 2 a 6), congruente, no obstante, con el hecho de que, para este conjunto de textos, aumenta en general el número de voces masculinas. Las declaraciones versan sobre hechos experimentados en primera persona por quienes son citados/as. Asimismo, sirven para atestiguar, por un lado, sus malas condiciones de vida, que, a su vez, justifican su elección como colectivo beneficiario y, por otro, para dar fe a las socias y los socios de Oxfam Intermón de que las actuaciones de la ONGD contribuyen efectivamente a mejorar su existencia. Por tanto, las categorías de experiencia personal y testigos aparecen entrelazadas (ver Figura 4).

El dato que más llama la atención con respecto al tipo de declaraciones incluidas en las piezas de Oxfam Intermón es la exigua cantidad de voces expertas procedentes del Sur. Resulta curioso, además, que, pese a que las citas atribuidas a las mujeres son mucho más cuantiosas que las adscritas a los hombres, el número de expertas y expertos no es proporcional con respecto a esa masiva presencia femenina, contabilizándose dos voces expertas de mujer por una masculina para cada periodo.

Figura 4. Tipos de citas para mujeres y hombres

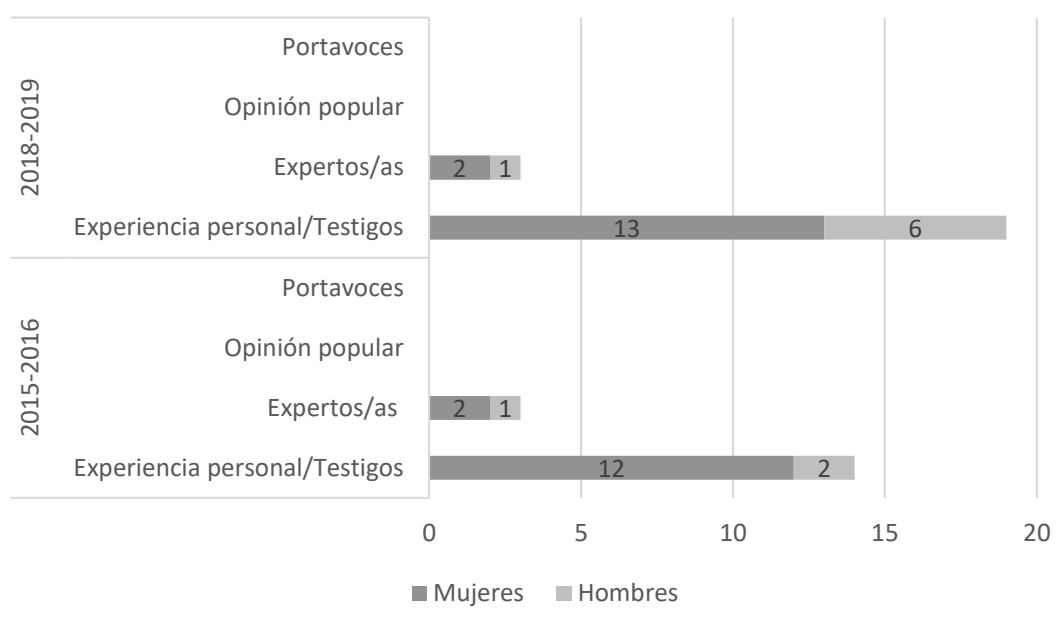

Fuente: elaboración propia 


\subsection{Representación visual de las mujeres del Sur}

Las dos muestras suman un total de 99 fotografías repartidas del siguiente modo: 54 correspondientes a la primera y 45 a la segunda. En ambas, destaca la notable presencia que las mujeres del Sur ocupan en la representación visual. Ellas son retratadas en 24 fotografías publicadas durante el periodo de 2015 y 2016, cifra que se eleva hasta las 30 en el periodo comprendido entre 2018 y 2019. Se podría añadir dos imágenes al primer conjunto de fotografías y una al segundo si, además, se contabilizan las tres en las que se captan manos de mujer en la realización de alguna tarea. Así pues, la población femenina adulta constituye el grupo poblacional más sobresaliente en la representación visual.

Son mostradas como colectivo único en 13 y 15 fotografías. En las dos muestras, se privilegian los retratos individuales: una mujer aparece en exclusiva en 8 de las 13 fotografías de la primera muestra mientras que, para la segunda, las 15 imágenes son retratos individuales. Por su parte, los hombres, el segundo colectivo con mayor representación visual en las piezas de Oxfam Intermón, tan solo están presentes en 14 y 15 fotografías. De nuevo, si se contabilizan las imágenes en las que se muestran sus manos, las cifras se elevan a 15 imágenes en el primer caso y a 18 en el segundo. Han sido retratados como colectivo único tan solo en 2 y 5 imágenes, siendo todas ellas retratos de un único hombre.

Pasando ahora a revisar la mezcla de colectivos que se refleja en las piezas de Oxfam Intermón, en la primera muestra, las mujeres del Sur fueron ligadas preferentemente a los/as menores ${ }^{10}$ (3 fotografías) y a los hombres (2 imágenes). En la segunda, el orden se invierte: acaparan el protagonismo junto a los varones en 5 imágenes por 4 en el que lo comparten con las y los menores. Sumando el conjunto de imágenes en las que ellas aparecen junto a la población infantil (niñas, niños o menores), ya sea con la presencia o no de otros colectivos (hombres del Sur, mujeres y hombres del Norte), se obtiene

10. Se utiliza esta categoría para aquellos/as infantes a los que resulta imposible adscribir a un sexo, femenino o masculino, a través de las imágenes. Somos conscientes de que reducir los sexos a los clásicos binarios es reduccionista, pero se opta por esta clasificación para adaptarnos a las fotografías analizadas, ya que no se ha observado ningún «cuerpo» que se salga de esta norma. 
un total de 6 imágenes en la primera muestra y de 10 en la segunda. Por su parte, el colectivo masculino es asociado con los niños en dos fotografías repartidas entre las dos muestras y con los menores en una de la primera. Si a estas cifras se les suman las imágenes en las que son acompañados por algún/a infante (niña, niño y/o menor) y, además, por otros colectivos (las y los adolescentes y las mujeres del Sur para la primera muestra y los hombres del Norte y de alcance global y las mujeres del Sur para la segunda) se obtiene un total de 6 fotografías para las piezas publicadas en el primer periodo estudiado y de 4 para las del segundo. De los datos se deduce que las mujeres son relacionadas con la población infantil en más del doble de ocasiones que los hombres en la segunda muestra y en mayor medida que en el primer conjunto de textos estudiados. Estas se convierten, pues, en las diferencias más significativas entre los dos periodos examinados con respecto a la representación visual (datos en las Figuras 5 y 6).

Figura 5. Número de fotografías con presencia de mujeres del Sur y colectivos a los que han sido vinculadas

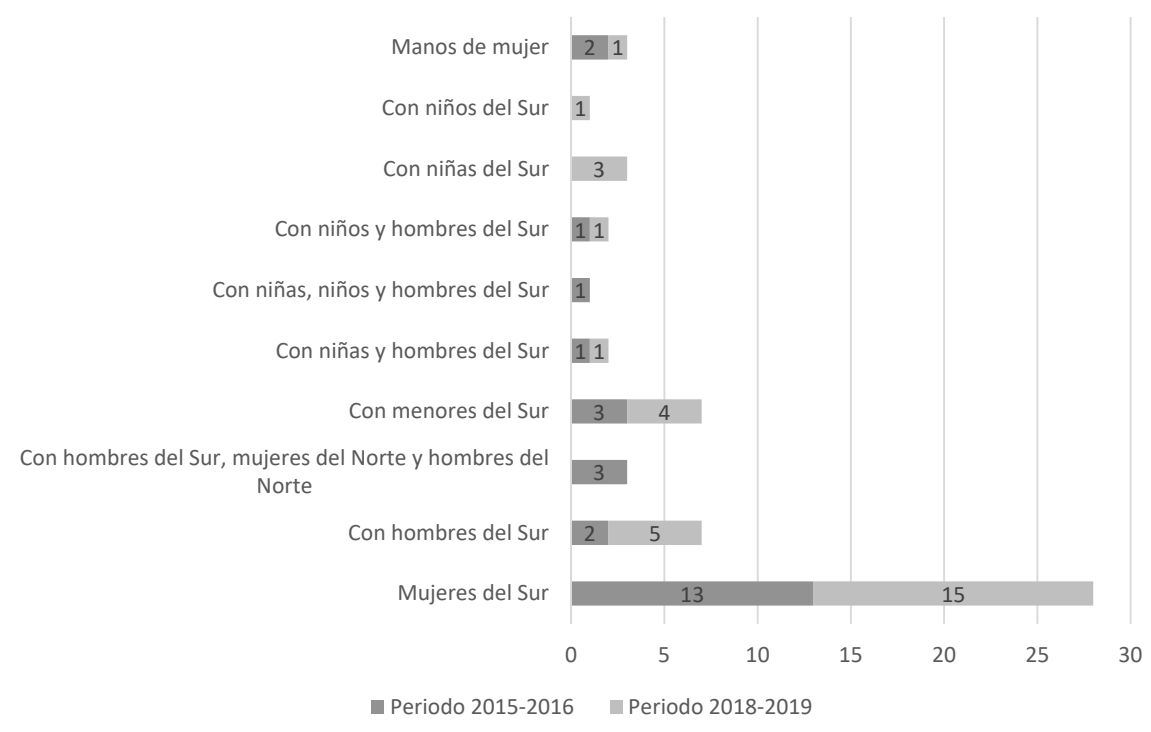

Fuente: elaboración propia 
La ambivalencia como rasgo definitorio del discurso de Oxfam Intermón sobre las mujeres del sur

Figura 6. Número de fotografías con presencia de hombres del Sur y colectivos a los que han sido vinculados

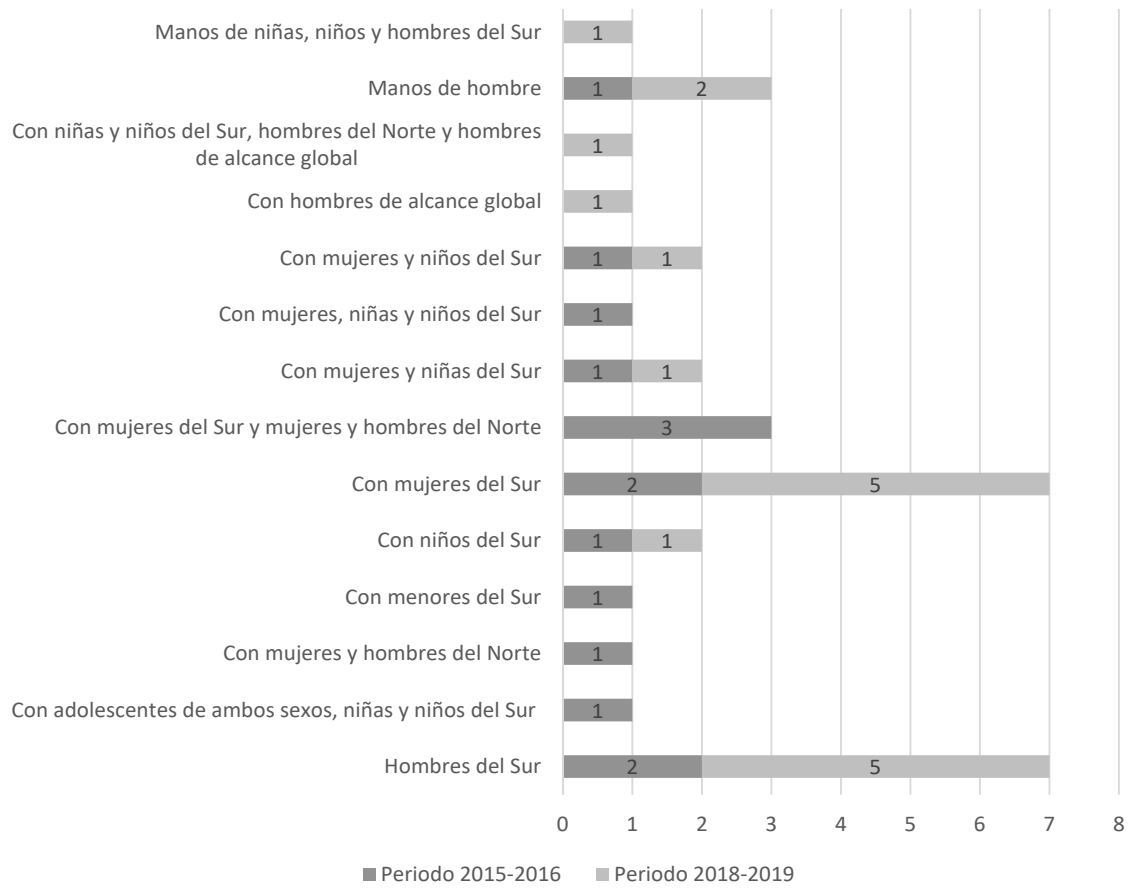

Fuente: elaboración propia ${ }^{11}$

Las fotografías subrayan en menor medida la condición de víctimas y beneficiarias de las mujeres que la parte textual. Dos pertenecientes a la primera muestra y una de la segunda reflejan en mayor medida la primera condición, encarnada en la figura de la refugiada, mientras que la segunda condición es evocada al captar a las mujeres durante la realización de actividades impulsadas por Oxfam Intermón. Tres fotografías del primer conjunto de textos retratan el encuentro de mujeres y hombres del Sur con los/as asociados/as de la ONGD y otra más capta la participación de la población femenina en actividades de

11. Bajo la denominación de «hombres de alcance global» se ha contabilizado a los cooperantes adscritos Oxfam cuando no se precisa a qué filial de esta federación de ONGD pertenecen.

Feminismo/s 39, January 2022, 149-180 
sensibilización. El número de imágenes correspondientes a su involucración en tales actividades asciende a tres en la segunda muestra (datos en la Figura 7).

La población femenina es vinculada a roles reproductivos y de cuidados y productivos casi en la misma proporción en las dos muestras analizadas. Con respecto al primer conjunto de textos y al primer tipo de funciones, predominan las fotografías en las que se las retrata como madres y encargadas de la recogida de agua ( 5 y 4 imágenes respectivamente). En cuanto a los roles productivos, se destaca su faceta como vendedoras, con un total de ocho fotografías. Si se suma el conjunto global de imágenes en las que aparecen como responsables de las tareas del hogar y de los cuidados familiares (madres, encargadas de la recogida de agua y de las compras) se obtienen 11 fotografías mientras que si se contabilizan aquellas en las que se las retrata como productoras (agricultoras y vendedoras), se obtienen 9 imágenes.

Es preciso matizar que el rol de la maternidad, aun siendo el segundo en importancia, no suele ser reflejado como función exclusiva. Es decir, no se retrata a las mujeres en posición estática sosteniendo a un/a bebé en sus brazos, imagen prototípica de la maternidad, sino que ellas aparecen realizando otras tareas como, por ejemplo, la recogida de agua o la participación en las actividades de Oxfam Intermón, en cuyo desarrollo son acompañadas por sus hijas e hijos (están junto a ellas mientras rellenan o cargan un bidón de agua o se encuentran sentados/as en el regazo de sus madres mientras ellas atienden las explicaciones de los cooperantes). Solo en una ocasión, en la que se retrata a una mujer refugiada con sus dos hijos bajo una tienda de campaña, se remite a esa imagen más tradicional y caritativa asociada en el imaginario occidental a la población femenina del Sur.

En la segunda muestra, el número de fotografías en las que aparecen asociadas a roles productivos y reproductivos y de cuidados casi resulta equivalente de nuevo. Entre los primeros, sobresalen la ganadería y el pastoreo, con 6 fotografías, y la agricultura, con 5. La representación de las mujeres del Sur como vendedoras decae con respecto a la primera muestra, pues únicamente se las caracteriza de este modo en tres ocasiones. Entre los roles reproductivos y de cuidados, la maternidad vuelve a ser el más destacado, estando presente en casi un tercio de las fotografías con presencia femenina (9). Por tanto, se hace más notable en este conjunto de piezas. De igual modo, aumenta el número de fotografías en las que ellas son mostradas 
como encargadas de la recogida de agua (6). En total, si se suman todas las fotografías en las que se asocia a la población femenina del Sur a funciones productivas (agricultura, ganadería y pastoreo, transformación de productos lácteos y vendedoras), se obtienen 15 imágenes, mientras que si se contabilizan aquellas que las retratan en papeles reproductivos y de cuidados, se arriba a la cifra de 16 imágenes.

Se registra el mismo tipo de representación de la maternidad que en la primera muestra. Salvo en una ocasión, en la que una mujer aparece sentada al lado de su hijo, con signos de desnutrición visibles en su cuerpo escuálido, sobre un fondo poco rico en detalles (la pared que se vislumbra al fondo parece la de una casa hecha con un material terroso, probablemente barro, lo que enfatiza la precariedad en la que vive la familia), la población femenina adulta del Sur no es retratada en exclusiva en la función de madre. Así pues, desempeña este rol al mismo tiempo que cuida su huerta, recoge agua para la unidad doméstica, estudia unos materiales formativos proporcionados por Oxfam Intermón o lleva a su ganado a pastar. Es decir, según se desprende de la representación, las mujeres del Sur combinan la maternidad con otros roles de tipo productivo, reproductivo y de cuidados.

Figura 7. Roles asociados a las mujeres del Sur en las fotografías

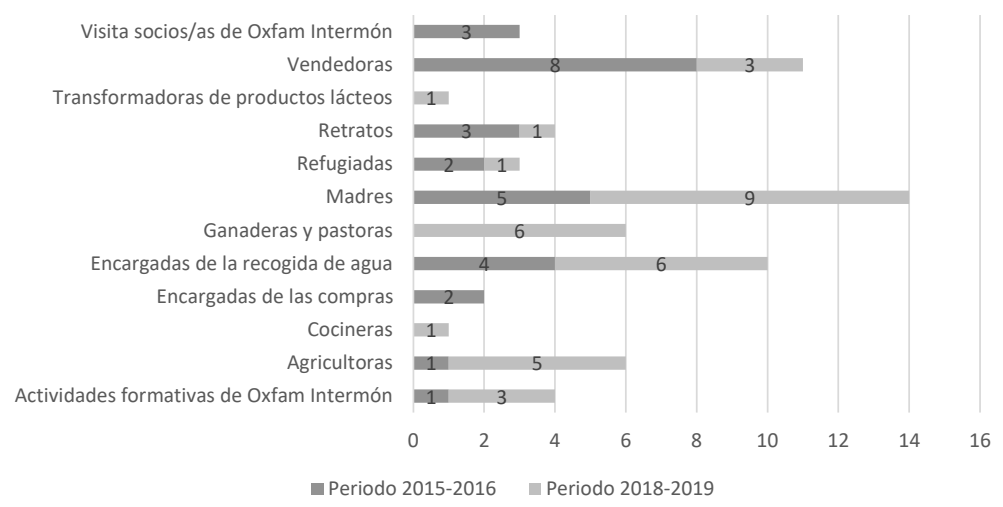

Fuente: elaboración propia ${ }^{12}$

12. Bajo la categoría «retratos» se incluyen aquellas fotografías que se focalizan en figuras femeninas del Sur, pero a las que no ha sido posible adjudicar un rol. En estos 
Como se comentó previamente, hay dos fotografías en la primera muestra y una en la segunda en las que se han retratado manos que, aparentemente, son de mujeres del Sur. En las tres ocasiones, se muestran las palmas de las manos que sostienen, por un lado, semillas de argán, con las que, según se explica en el texto, elaboran el aceite que es incorporado a los productos de comercio justo que Oxfam Intermón vende en sus tiendas en España y, por otro, unas mazorcas de maíz que remiten a los estragos que la sequía está provocando entre la población agrícola de Malawi. Aunque, en estas imágenes, las figuras femeninas son mostradas de manera parcial y, por tanto, podría pasar fácilmente desapercibido el hecho de que las manos pertenezcan a las mujeres, es interesante hacer notar que remiten y subrayan, una vez más, su rol como productoras.

Finalmente, el análisis ha desvelado que Oxfam Intermón opta por una representación que, simbólicamente, connota igualdad entre las mujeres retratadas y el público lector. Predominan las imágenes captadas a la altura de los ojos de sus protagonistas para los dos periodos analizados con un número de imágenes coincidente (18). La cifra no sufre ninguna variación a pesar de que la cantidad de mujeres retratadas durante el segundo periodo es mayor. Por su parte, las fotografías que marcan una relación de superioridad y de inferioridad entre quienes aparecen retratadas y quienes las observan son iguales para el primer periodo (3) y aumentan sensiblemente para la segunda muestra, quedando en 7 y 5 respectivamente. Así pues, se deduce que la ONGD, cuando se decide por marcar una relación jerárquica, opta preferentemente por otorgar poder, simbólicamente hablando, a las mujeres que protagonizan sus fotografías.

Además, privilegia las imágenes en las que ellas no interaccionan con el público lector para los dos periodos estudiados. De este modo, las 10 fotografías de la primera muestra en las que sí se registra interacción entre las mujeres del Sur y quienes las observan desde las páginas de la revista pasan, en el segundo periodo estudiado, a 11. Son, por tanto, las imágenes

casos, ellas o bien posan ante la cámara o bien se sitúan frente al objetivo que las capta, abstraídas del mismo, sin desarrollar, aparentemente, ninguna actividad. Por ejemplo, miran a algo que sucede fuera de campo o dirigen sus ojos hacia el suelo, manteniéndose, en ambos casos, en posición estática. 
en las que no existe interacción las que más crecen en este sentido: las 14 de la primera muestra se convierten en 19 en la segunda.

\section{CONCLUSIONES}

El análisis permite concluir que el rasgo predominante a la hora de representar a la población femenina del Sur en las revistas para socias y socios de Oxfam Intermón es la ambivalencia. Se confirma la abundante presencia de rostros femeninos ya señalada en estudios previos (Bringas, 2010; Flores Martos, 2018; Martín Nieto, 2009; Saiz, 2007). Se parte de las mujeres para construir la representación de las comunidades del Sur. Este hecho puede ser beneficioso, pues permite visibilizarlas y prestar atención sobre sus particulares circunstancias.

No obstante, en el caso estudiado, esta notable presencia femenina va asociada a una caracterización del Sur como especialmente vulnerable y necesitado de protección. Por tanto, no se han superado todavía los clásicos papeles de víctimas y beneficiarias, pues a ellos se vincula a las mujeres de manera mayoritaria en los dos periodos estudiados. El rol de supervivientes, evocado en un único texto de la primera muestra, tiene una presencia anecdótica, no poniéndose en valor, por tanto, la capacidad de resiliencia de la población femenina del Sur, así como sus propias formas de resistencia frente a la opresión. No obstante, la caracterización como víctimas y beneficiarias resulta menos evidente en las fotografías. Además, en los recursos visuales, se opta por presentarlas en relaciones simbólicas de poder equilibradas para con el público lector.

Por su parte, la representación más habitual de las mujeres del Sur como madres y encargadas de las tareas del hogar y el cuidado familiar es complementada con nuevas funciones. No se trata de que los roles reproductivos y de cuidado hayan dejado de visibilizarse tanto en la parte escrita como visual de los textos. De hecho, la maternidad resulta omnipresente en la mayoría de ellos. Sin embargo, esta representación es contrarrestada con otra imagen que las perfila, sobre todo, como esforzadas trabajadoras en la agricultura, la ganadería o el comercio y/o como piezas clave en el bienestar de sus comunidades. Es decir, se produce una imbricación entre los roles reproductivos y de cuidados, productivos y comunitarios. Este punto es 
particularmente notable en la representación visual, en la que se muestra al colectivo femenino en el desempeño de distintas actividades (recogida de agua, actividades de sensibilización, etc.) acompañadas por sus hijas e hijos.

No obstante, los roles productivos a los que se las vincula no están exentos de contrariedad. Ellas son caracterizadas, fundamentalmente, como protagonistas de una economía de subsistencia que resulta más una extensión de sus actividades reproductivas y de cuidados (agricultoras encargadas de pequeñas huertas, ganaderas que destinan su producción, principalmente, a la alimentación de la familia, comerciantes que usan sus ingresos para cubrir necesidades familiares, etc.) que una actividad económica de alto rendimiento. Implícitamente, se extrae que este último ámbito es copado por la población masculina quedando ellas asociadas a una producción de menor categoría.

$\mathrm{Al}$ igual que es mayoritaria la presencia femenina en las piezas analizadas, también lo son sus voces a través de citas de carácter experiencial y testimonial. Es decir, sí, se les da voz para que relaten sus particulares problemas desde su punto de vista, pero, al mismo tiempo, las declaraciones se emplean para justificar la propia labor de Oxfam Intermón y apenas se incluyen voces expertas del Sur. La ONGD pierde la oportunidad de enriquecer sus textos con otro tipo de citas como podrían ser las recabadas entre las filas de sus contrapartes locales, organizaciones en las que están presentes mujeres cualificadas y preparadas para hablar tanto de sus sociedades como de las intervenciones sobre el terreno. En definitiva, se observa una asunción tan solo parcial y, en algunos casos, superficial de las recomendaciones sugeridas por la Coordinadora (2019b, p. 29-32). En consecuencia, no se ha superado la representación estereotipada denunciada por la literatura académica, aunque se detectan intentos incipientes de completar y matizar la representación ofrecida sobre las mujeres del Sur.

Con respecto a la comparativa entre los periodos de análisis, no se han apreciado diferencias sustanciales entre las muestras. Se ha seguido la misma línea de representación tanto a nivel textual como visual con un ligero aumento de la presencia femenina en las piezas publicadas en el segundo periodo. Los roles evocados apenas sufren variación, a excepción de un mayor énfasis en la maternidad y las tareas del hogar (sobre todo, la recogida de agua) registrado en la segunda muestra. El tipo de citas incluidas y la 
relación y la interacción sociales que se establece en la parte visual, a nivel simbólico, entre público lector y representadas se ha mantenido.

Finalmente, es preciso tener en cuenta que este estudio es una primera aproximación a los mensajes de Oxfam Intermón y, en general, de las ONGD, de corte cuantitativo fundamentalmente. Para completar la caracterización que esta entidad efectúa sobre la población femenina, se prevén ulteriores análisis que se detengan en desentrañar cualitativamente la imagen que construyen en torno a las mujeres del Sur.

\section{BIBLIOGRAFÍA}

Alonso, H. (14 de febrero de 2018). Abusos sexuales: sólo seis de las diez grandes ONG internacionales acceden a revelar sus datos. Actualidad humanitaria. https:// actualidadhumanitaria.com/abusos-sexuales-solo-seis-de-las-diez-grandes-ong-internacionales-acceden-a-revelar-sus-datos/

Alonso, H. (22 de febrero de 2018). Abusos en ONG: en 2017 fueron despedidos al menos 124 trabajadores por mala conducta sexual. Actualidad humanitaria. https://actualidadhumanitaria.com/abusos-en-ong-en-2017-fueron-despedidos-mas-de-120-trabajadores-por-mala-conducta-sexual/

Aziz, S. (13 de febrero de 2018). Como extrabajadora de varias ONG, las revelaciones de Oxfam no me han sorprendido en absoluto. Eldiario.es. https://www. eldiario.es/internacional/theguardian/extrabajadora-humanitaria-revelaciones-oxfam-sorprendido_1_2794469.html

Betrisey, D. J. y Gordo, Á. J. (2007). Ocultar mostrando: los medios de comunicación y el maltrato hacia las mujeres. En B. Biglia y C. San Martín (Coords.), Estado de wonderbra. Entretejiendo narraciones feministas sobre las violencias de género (pp. 95-106). Virus editorial.

Bringas, A. M. (2010). Oscuros objetos de deseo: construcciones culturales del cuerpo femenino negro en el discurso publicitario. En B. Martín (Coord.), Violencias (in) visibles. Intervenciones feministas frente a la violencia patriarcal (pp. 115-138). Icaria.

Canga Larequi, J. (1994). El diseño periodístico en prensa diaria. Bosch.

Castro Vázquez, O. (2010). La otra violencia de los medios de comunicación: una aproximación a la construcción discursiva de las relaciones de género. En B. Martín (Coord.), Violencias (in)visibles. Intervenciones feministas frente a la violencia patriarcal (pp. 91-113). Icaria. 
La ambivalencia como rasgo definitorio del discurso de Oxfam Intermón sobre las mujeres del sur

Coordinadora de ONG para el Desarrollo-España (2019a). Código de conducta. https://coordinadoraongd.org/wp-content/uploads/2019/07/ Co\%CC\%81digo-de-conducta-2019_COORDI_v2.pdf

Coordinadora de ONG para el Desarrollo-España (2019b). Guía práctica para la comunicación de las ONG: https://coordinadoraongd.org/wp-content/ uploads/2020/06/Guia_CodigoConducta_DEF.pdf

Coordinadora de ONG para el Desarrollo-España (2019c). Informe del sector. Coordinadoraong.org. https://informedelsector.coordinadoraongd.org/ informe-2019/en-otros-paises/

Darnton, A. y Kirk, M. (2011). Buscando marcos: nuevas formas de implicar a la ciudadanía del Reino Unido con la pobreza global. Oxfam \& UK Aid.

De Silva, H. y Gaudin, J. (2007). Interpreting the Visual. A resource book for teachers. Phoenix Education.

Efe (31 de junio de 2018). El Parlamento británico dice que el abuso sexual es un mal «endémico» de ONG. Publico.es. https://www.publico.es/sociedad/ayuda-desarrollo-parlamento-britanico-dice-abuso-sexual-mal-endemico-ong.html

El Proyecto de Monitoreo Global de Medios (2015). ¿Quién figura en las noticias?. https://whomakesthenews.org/wp-content/uploads/who-makes-the-news/ Imported/reports_2015/global/gmmp_global_report_es.pdf

Erro, J. (2002). Comunicación, desarrollo y ONGD. Hegoa.

Flores Martos, J. A. (2018). «Nulla ethica sine aesthetica»: una etnografía de usos de imágenes en ONGD. En J. Chaves y L. M. Juárez (Eds.), Cooperación al desarrollo. Derechos humanos y políticas de comunicación (pp. 125-146). Anthropos.

Garrido, J. D (2007). El lado oscuro de las ONG. Arcopress.

Giró, X. (2017). Modos híbridos y complejos de informar sobre cooperación. Anuario Electrónico de Estudios en Comunicación Social «Disertaciones», 10(1), 84-107. https://doi.org/10.12804/revistas.urosario.edu.co/disertaciones/a.4914 Gómez Pérez, J. M., Jiménez Rivero, M., Rosado Morón, I. y Sánchez Jacob, E. (2019). Nadie dijo que fuera fácil. Un relato colectivo, optimista y cuestionador sobre cómo las ONGD implicamos a la ciudadanía. ONGAWA.

González Luis, H. (2006). Estrategias de comunicación en las ONG de Desarrollo. Departamentos, funciones e impacto en los medios. CIDEAL-Fundación Asistencia Técnica para el Desarrollo.

Gregorio, C. (2009). Colonizando los cuerpos. Fronteras en la representación de las 'mujeres inmigrantes'. Cuadernos del Ateneo, 28, 47-56. 
Halliday, M. A. K. (1982). El lenguaje como semiótica social. La interpretación social del lenguaje y el significado. Fondo de Cultura Económica.

Herranz de la Casa, J. M. (2007). La gestión de la comunicación como elemento generador de transparencia en las organizaciones no lucrativas. Revista CIRIEC-España, 57, 5-31.

Iranzo, A. (2017). La comunicación de las ONGD: la lenta erosión del enfoque caritativo dominante. Anuario Electrónico de Estudios en Comunicación Social «Disertaciones», 10(1), 66-83. https://doi.org/10.12804/revistas.urosario.edu.co/disertaciones/a.4910

Iranzo, A., Farné, A. y Lorente, M. (2015). El treball comunicatiu de les ONG de la FCONG: recursos, prioritats i discursos. Federació Catalana d'ONG per al Desenvolupament.

Kress, G. R. y Van Leeuwen, T. (2006). Reading Images. The Grammar of Visual Design. Routledge Press. https://doi.org/10.4324/9781003099857

López García, J. (2005). Sentidos y efectos de la fotografía para la solidaridad. En C. Ortiz García, C. Sánchez Carretero y A. Cea Gutiérrez (Coords.), Maneras de mirar. Lecturas antropológicas de la fotografía (pp. 83-108). CSIC.

Macken-Horarik, M. (2004). Interacting with multimodal text: reflections on image and verbiage in ArtExpress. Visual Communication, 3(1), 5-26. https://doi.org/10.1177/1470357204039596

Marcellesi, F. (2012). Cooperación al posdesarrollo. Bases teóricas para la transformación ecológica de la cooperación al desarrollo. Bakeaz.

Martín Nieto, R. (2009). El tercer mundo representado. La imagen como nido de estereotipos. Icono 14. Revista de comunicación y nuevas tecnologías, 52-171. https://doi.org/10.7195/ri14.v7i2.321

Martínez Lirola, María (2010). Explorando nuevas formas de violencia de género: la mujer como objeto de los folletos de clínicas de estética. Global Media Journal Mexico, 7(13), 80-94.

Martínez Lirola, M. (2017). La importancia del análisis crítico del discurso y la gramática visual para analizar textos. Propuesta de actividades enmarcadas en la educación para el desarrollo, la educación con perspectiva de género y la educación para la paz. Comares.

Martínez Sánchez, J. L. (1998). La imagen de las ONG de desarrollo. Para ir dimensionando el Tercer Sector. IEPALA.

Murguialday, C., Vázquez, N. y González, L. (2008). Un paso más: evaluación del impacto de género. Cooperacció. 
Nerín, G. (2011). Blanc bo busca negre pobre. Crítica de la cooperación i les ONG. La Campana.

Nos Aldás, E. (2003). Discurso publicitario y sensibilización en las ONGD: de la función social de la publicidad a la responsabilidad de la comunicación social. En V. J. Benet, y E. Nos Aldás (Eds.), La publicidad en el Tercer Sector. Tendencias y perspectivas de la comunicación solidaria (pp. 83-127). Icaria.

Nos Aldás, E. (2007). Lenguaje publicitario y discursos solidarios: eficacia publicitaria, ¿eficacia cultural? Icaria.

Nos Aldás, E. (2010). Comunicación, cultura y educación para la solidaridad y el desarrollo. En T. Burgui y J. Erro (Coords.), Comunicando para la solidaridad y la cooperación. Cómo salir de la encrucijada (pp. 113-134). Foro Comunicación, Educación y Ciudadanía.

Nos Aldás, E. (2019) Comunicación transgresora de cambio social. Universitat Jaume I. https://doi.org/10.6035/Sapientia158

O'Neill, S. (9 de febrero de 2018). Oxfam in Haiti: «It was like a Caligula orgy with prostitutes in Oxfam T-shirts». The Times. https://www.thetimes.co.uk/article/oxfam-in-haiti-it-was-like-a-caligula-orgy-with-prostitutes-in-oxfam-tshirts-p32wlk0rp

Picas Contreras, J. (2001). El papel de las organizaciones no gubernamentales y la crisis del desarrollo. Una crítica antropológica a las formas de cooperación [Tesis Doctoral, Universidad de Barcelona]. https://www.tesisenred.net/ handle/10803/705\#page $=1$

Porras, L. y Molina, S. (2011). Manual de género para periodistas. Recomendaciones básicas para el ejercicio del periodismo con enfoque de género. http://www. americalatinagenera.org/es/documentos/Folleto_ManualdeGenero.pdf

Ratcliffe, R. y Quinn, B. (11 de febrero de 2018). Oxfam: fresh claims that staff used prostitutes in Chad. The Guardian. https://www.theguardian.com/ world/2018/feb/10/oxfam-faces-allegations-staff-paid-prostitutes-in-chad

Rizzardini, M. (2002). La producción de conocimiento y comunicación de las ONGD. Entre la ideología dominante y un imaginario social alternativo. En M. Revilla (Ed.), Las ONG y la política (pp. 286-345). Istmo.

Saiz, V. (2007). Una construcción 'solidaria' de la subalternidad: mujeres en la publicidad de las ONGD. En M. J. Sánchez Leyva y A. Reigada (Coords.), Crítica feminista y comunicación (pp. 215-244). Comunicación Social Ediciones y Publicaciones. 
Santolino, M. (2010). Recuperando la esencia: las ONGD como agentes de comunicación para el cambio social. En T. Burgui y J. Erro (Coords), Comunicando para la solidaridad y la cooperación. Cómo salir de la encrucijada (pp. 221256). Foro Comunicación, Educación y Ciudadanía.

Santos, Boaventura de Sousa (2011). Introducción: las epistemologías del Sur. CIDOB, 9-22.

Tyner, K. E. y Ogle, J. P. (2009). Feminist Theory of the Dressed Female Body: A Comparative Analysis and Applications for Textiles and Clothing Scholarship. Clothing and Textiles Research Journal, 27(2), 98-121. https:// doi.org/10.1177/0887302X08322715 